Fifth International Conference on Sustainable Construction Materials and

Technologies. http://www.claisse.info/Proceedings.htm

\title{
LABORATORY STUDY TO EVALUATE THE EFFECT OF WASTE TONER ON DYNAMIC CREEP OF ASPHALT CONCRETE MIXTURES
}

\author{
Taisir S. Khedaywi \\ Professor of Civil Engineering, Jordan University of Science and Technology, P.O.Box \\ 3030, Irbid, 22110, Jordan, E-mail: khedaywi@just.edu.jo
}

\begin{abstract}
Large quantities of waste toner are rejected as waste. This material creating an environmental pollution and causing costly disposal problems. The objective of this research is to determine the effect of waste toner on dynamic creep of asphalt concrete mixtures. Waste toner was used as an additive to the asphalt cement with five contents $(0,5,10,15$ and $20 \%)$ by volume of binder. Then, they were exposed to simulation of creep test through Universal Testing Machine (UTM). Three testing temperature levels $\left(5,25\right.$ and $\left.40^{\circ} \mathrm{C}\right)$ and three loading frequencies $(1,4$ and $8 \mathrm{~Hz})$ were used. Resilient modulus, creep stiffness and accumulated strain were measured. Tests results show that resilient modulus and creep stiffness increasing then decreasing with the increasing \% waste toner in the binder. Tests results also show that accumulated strain decreasing with the increasing $\%$ waste toner in the asphalt concrete mixtures.
\end{abstract}

Keywords: Waste toner, creep, asphalt, resilient modulus, stiffness

\section{INTRODUCTION/ LITERATURE REVIEW}

All over the world, large quantities of waste toner are rejected as wastes. This material creating environmental pollution and causing costly disposal problems. According to some estimates in the USA, the total resulting both from manufacturing and from spent cartridges exceeds 9,000 metric tons per year (Diamond, 1996). Obviously, not all manufacturers produce the same amount of waste. The amount depends on the technology and on the quantity of the toner produced in each plant. One manufacturer reports production of over 600 tons of waste toner per year based on a toner production 
level of about 7, 700 tons per year (about 9 percent waste). In this research, an attempt has been made to partially overcome these problems through using this waste in asphalt concrete mixtures for flexible pavement and road surfaces.

Many researchers have been indicated that it is possible to use additives to improve the performance of asphalt concrete mixtures. There are a number of asphalt additives (or modifier) in the market. Several researchers have investigated the role of different extender and filler on the performance of asphalt concrete mixtures (Terrel and Epps, 1998).

Khedaywi et al. (1993) investigated the effect of rubber on properties of asphalt concrete mixtures. Results indicated that asphalt-rubber concrete mixtures have lower stability and higher flow than do asphaltic concrete mixtures without rubber.

Al-Masaeid et al. (1994) evaluated the effect of olive husk on properties of bituminous concrete. They concluded that the olive husk material improved workability and stability and reduced the optimum binder content of bituminous mixes.

Khedaywi (2014) conducted study on utilizing waste toner in asphalt cement. The test results were analyzed to determine the effect of the waste toner content on the measured properties of the asphalt cement. Tests results showed that with the increase in the waste toner content in the binder, penetration and ductility decreased while specific gravity, softening point, flash point, fire point and rotational viscosity increased.

As stated in Button et al. (1996), "after evaluating the toner-modified asphalt in the laboratory in Oklahoma in 1990, Ayers and Tripathi (1994) demonstrated that waste toner retrieved from Xerox duplicators could be successfully incorporated into asphalt cement and asphalt concrete". When they blended 2 percent to 10 percent toner by weight with asphalt cement, the temperature susceptibility of the resulting binders was reduced. When blending waste toner with asphalt paving mixtures, they found that increasing toner content successively increased Hveem stability. Dry toner added to asphalt appeared to be the most successful method for field operations. They concluded that Xerox toner could be a beneficial additive to asphalt paving mixtures.

As indicated by Solaimanian et al. (1998) as the amount of waste toner increases, the stiffness and viscosity of the modified binder increase. Higher stability and strength are also observed in modified mixtures with toner compared with unmodified blends. According to this study, good performance is expected where permanent deformation is the major concern. Four different levels of waste toner modification and four different toners were used to study the effect of toner on asphalt properties. A control mixture was employed with two dosage rates to measure the effect of waste toner on asphalt mixture characteristics. The study recommends incorporating the toner powder into the asphalt cement since the use of dispersing oil will result in a softened binder, while water will result in foamed asphalt. Stirring time is emphasized so that a complete reaction takes place and a homogeneous material is obtained. Shear rate during addition is an important factor influencing the properties of the toner-asphalt blend.

Alsheyab and Khedaywi (2013) studied the effect of using electric arc furnace dust on the properties of the asphalt cement. It was found that the penetration and ductility 
decreased with the increase in the dust concentration in the binder, while specific gravity, softening point, flash point, fire point and rotational viscosity increased.

Abu Salem et al. (2017) evaluated the effect of waste glass on properties of asphalt concrete mixtures. They found that waste broken glass can be used in asphalt concrete with the maximum size of $2.36 \mathrm{~mm}$ and the optimal replacement ratio of $10 \%$ by volume of binder which satisfied all the requirements as per the specification limits. Two cases were reported where waste toner has been used in asphalt pavements on an experimental basis. First comes from the work of Ayers and Tripathi (1994) who reported on a test section laid in Oklahoma in 1990, after a period of evaluating the toner modified in the laboratory. The test section is still in a good condition. Waste toner was directly added to the aggregate before blending with asphalt.

Second experiment is reported by Diamond (1996) for resurfacing on I-15 in Nevada. Waste toner was simply added to the aggregate. Overall dissatisfaction was expressed. There is no evidence of how much of the toner was used in this project and for what length of the road.

\section{OBJECTIVES}

The objectives of this research are as follows:

(1) To investigate the feasibility of using waste toner as an additive to asphalt concrete mixtures.

(2) To analyze the effect of this waste toner on resilient modulus, creep stiffness, and accumulated micro-strain of asphalt concrete mixtures.

(3) To determine the optimum waste toner that should be added to asphalt cement to give the best properties of asphalt concrete mixtures.

\section{MATERIAL USED}

The materials used in the research are:

\section{Aggregate}

One type of limestone aggregate was used, which was brought from Al-Halabat queries in the northern part of Jordan. Gradation type was used according to the Ministry of Public Works and Housing (MPWH) specifications in Jordan. Table 1 shows the aggregate gradation. Table 2 presents aggregate properties used in this research using American Society for Testing and Materials test method (ASTM). 
Table 1. Aggregate Gradation Used in the Mixtures

\begin{tabular}{|l|c|c|}
\hline \multicolumn{1}{|c|}{ Sieve size } & $\begin{array}{c}\text { Specification limits* } \\
\text { (\% Passing) }\end{array}$ & $\begin{array}{c}\text { \% Passing } \\
\text { (midpoint) }\end{array}$ \\
\hline $1 "(25 \mathrm{~mm})$ & 100 & 100 \\
\hline $3 / 4 "(19 \mathrm{~mm})$ & $90-100$ & 95 \\
\hline $1 / 2 "(12.5 \mathrm{~mm})$ & $71-90$ & 80.5 \\
\hline $3 / 8 "(9.5 \mathrm{~mm})$ & $56-80$ & 68 \\
\hline No.4 $(4.75 \mathrm{~mm})$ & $35-65$ & 50 \\
\hline No.8 $(2.35 \mathrm{~mm})$ & $23-49$ & 36 \\
\hline No.20 $(850 \mu \mathrm{m})$ & $14-43$ & 28.5 \\
\hline No.50 $(300 \mu \mathrm{m})$ & $5-19$ & 12 \\
\hline No.80 $(180 \mu \mathrm{m})$ & $4-15$ & 9.5 \\
\hline No. $200(75 \mu \mathrm{m})$ & $2-8$ & 5 \\
\hline
\end{tabular}

*Ministry of Public Works and Housing (MPWH) specification wearing mix.

Table 2. Aggregate Properties Used in the Research.

\begin{tabular}{|c|c|c|c|c|}
\hline $\begin{array}{c}\text { Aggregate type } \\
\text { (Limestone) }\end{array}$ & $\begin{array}{c}\text { ASTM test } \\
\text { Designation }\end{array}$ & $\begin{array}{c}\text { Bulk specific } \\
\text { Gravity }\end{array}$ & $\begin{array}{c}\text { Apparent specific } \\
\text { Gravity }\end{array}$ & $\begin{array}{c}\text { Absorption } \\
(\%)\end{array}$ \\
\hline Coarse & C127 & 2.523 & 2.660 & 2.03 \\
\hline Fine & C128 & 2.488 & 2.702 & 3.89 \\
\hline Mineral filler & C128 & 2.65 & 2.788 & 4.2 \\
\hline
\end{tabular}

\section{Asphalt Cement}

One penetration grade of asphalt cement (60-70) was used in this study. Table 3 presents the physical properties of this asphalt binder using American Society for Testing and Materials test method (ASTM).

Table 3. Physical Properties of Asphalt

\begin{tabular}{|l|l|c|}
\hline Properties & \multicolumn{1}{|c|}{ Methods } & $\begin{array}{c}\text { Test } \\
\text { Result }\end{array}$ \\
\hline Penetration $(0.1 \mathrm{~mm}), 25^{\circ} \mathrm{C}, 100 \mathrm{~g}, 5 \mathrm{sec}$ & ASTM D 5 & 65 \\
\hline Ductility $(\mathrm{cm})$ at $25^{\circ} \mathrm{C}$ & ASTM D 113 & 108 \\
\hline Specific gravity at $25^{\circ} \mathrm{C}$ & ASTM D 70 & 1.010 \\
\hline
\end{tabular}




\begin{tabular}{|l|l|l|}
\hline Softening point $\left({ }^{\circ} \mathrm{C}\right)$ & ASTM D 36 & 50.3 \\
\hline Flash Point $\left({ }^{\circ} \mathrm{C}\right)$ & ASTM D 92 & 312.5 \\
\hline Fire Point $\left({ }^{\circ} \mathrm{C}\right)$ & ASTM D 92 & 318 \\
\hline
\end{tabular}

\section{Waste Toner}

Waste toner is the dry ink used in copiers and laser printers. It is in the form of fine solid powder, black in color and with slight plastic oder. The toner considered to be waste may come from either the Manufacturing process or from copiers' machines and laser printers. From the previous studies on waste toner and asphalt concrete mixtures, there has never been a negative health impact by using waste toner in the flexible pavement. Based on USA federal regulations, the toner is non-toxic and does not generate hazardous waste (Solaimanian et al. 1980).

\section{LABORATORY WORK}

\section{Preparations of Waste Toner Asphalt Binders}

It has been decided to study different volume percentages of toner - asphalt binder. The studied percentages are: 5, 10, 15 and $20 \%$ of toner by volume of binder. For each experiment, the corresponding weight to each volume percentage for both the asphalt and toner was prepared. The asphalt was heated while adding the corresponding volume of toner with mixing to guarantee a homogeneous mixture for each experiment. At the end of the mixing operation, the toner -asphalt binder was mixed with the heated aggregate to prepare toner- asphalt concrete specimens according to ASTM procedure.

\section{Determination the Optimum Asphalt Content for Conventional Mixes}

To determine the optimum asphalt content by weight of total mix, Marshall mix design procedure (ASTM D1559) was followed as a part of this study. Three specimens at each asphalt content (4.0, 4.5, 5.0, 5.5, and 6\%) were tested for stability, flow, air voids, unit weight, and voids in mineral aggregate. The optimum asphalt content, which was the average of asphalt contents that meet optimum stability, maximum unit weight, and $4 \%$ air voids, was determined. The value of the optimum asphalt content found to be $5.4 \%$ by total weight of asphalt concrete mixture.

\section{Dynamic Creep Test}

The dynamic creep test was conducted to evaluate the effect of toner on pavement design. The test was performed using Universal Testing Machine. The tests were carried out according to British Institute Standards test (BS). Haversine loading was applied without impact and with loads varying between $(0$ and $100 \mathrm{kPa})$. 
Tests were conducted at the temperature 25,40 and $55^{\circ} \mathrm{C}$ and three frequencies were adopted (8, 4, and $1 \mathrm{~Hz})$. Resilient modulus, creep stiffness and accumulated micro-strain were measured using Universal testing machine and environmental chamber as seen in Figure 1.

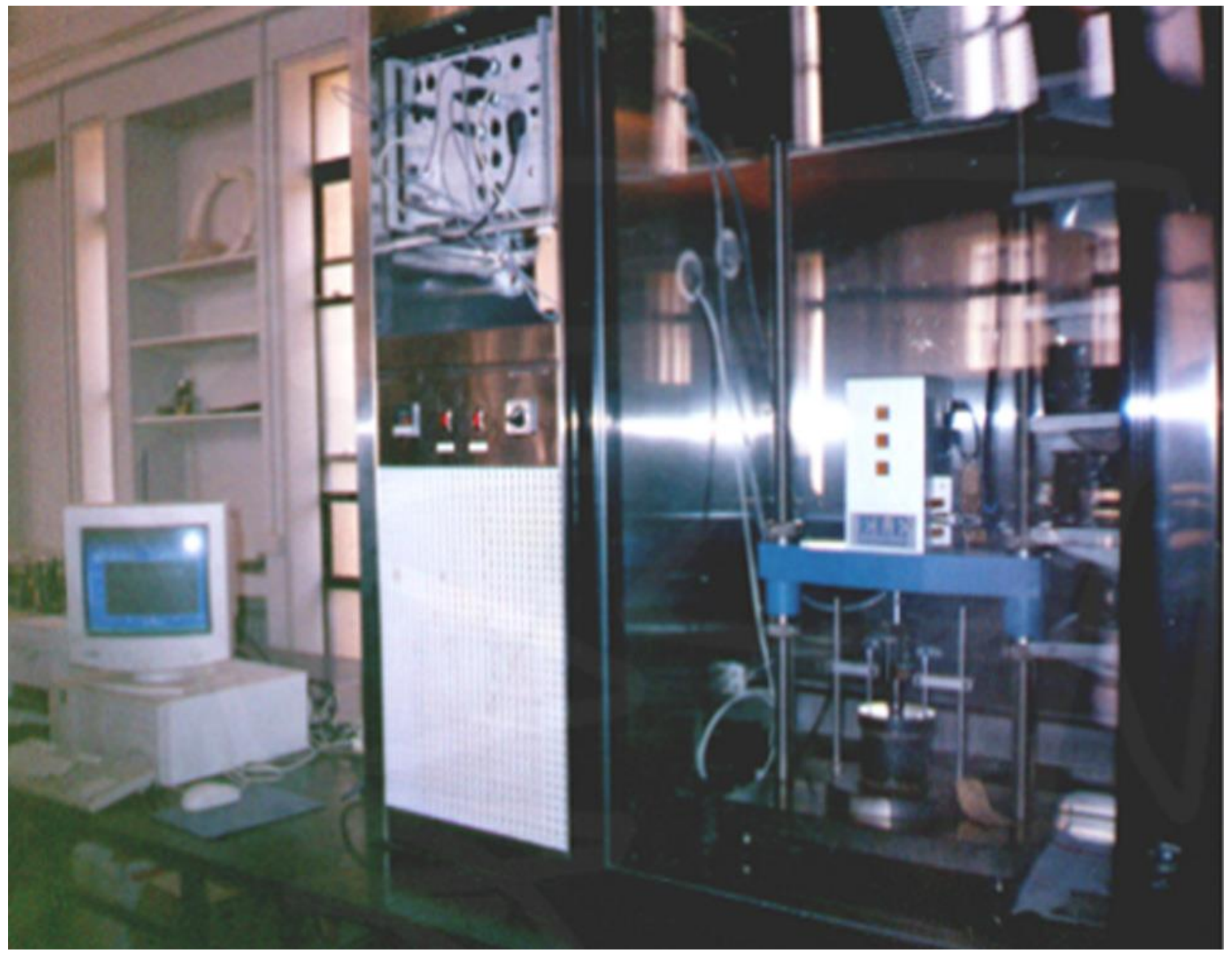

Figure1. Universal Testing Machine (UTM) and Environmental Chamber

\section{TEST RESULTS AND DISCUSSION}

Results of the study are illustrated in Tables 4 to 6 which represent the effect of waste toner on the three studied parameters: resilient modulus; creep stiffness and accumulated 
strains consecutively. Each table illustrates the results at three frequencies 1,4 and $8 \mathrm{~Hz}$ and at thee temperatures 5,25 and $40^{\circ} \mathrm{C}$.

\section{Effect of Waste Toner on Resilient Modulus}

Table 4 shows the relationship between increasing the percent waste toner and the response of resilient modulus (RM) at different operational conditions of frequencies and temperatures. Following sections present the effect of temperature at constant frequency on RM and the effect of frequency at constant temperatures on RM.

\section{Effect of temperature at constant frequency}

At $1 \mathrm{HZ}$, the resilient modulus increases then decreases with the increasing the percentage of waste toner in the binder at all the temperatures. The effect of temperature on the resilient modulus was highest at $5^{\circ} \mathrm{C}$ followed by $25^{\circ} \mathrm{C}$ and then $40^{\circ} \mathrm{C}$. For each temperature at $1 \mathrm{~Hz}$, the optimum value of waste toner is $10 \%$. Taking into consideration that the resilient modulus is described as the ratio of applied deviator stress to recoverable or resilient strain, it seems that the increase of temperature enhances the recoverable strain, which makes the resilient modulus go down, indicating a better performance characteristic of pavement with waste toner modified asphalt. At $4 \mathrm{~Hz}$, the resilient modulus increases then decreases with the increasing the percentage of waste toner in the binder at all the temperatures. The effect of temperature on the resilient modulus was highest at $5^{\circ} \mathrm{C}$ followed by $25^{\circ} \mathrm{C}$ and then $40^{\circ} \mathrm{C}$. For each temperature at 4 $\mathrm{Hz}$, the optimum value of waste toner is $10 \%$. At $8 \mathrm{~Hz}$, the resilient modulus increases then decreases with the increasing the percentage of waste toner in the binder at all the temperatures. The effect of temperature on the resilient modulus was highest at $5^{\circ} \mathrm{C}$ followed by $25^{\circ} \mathrm{C}$ and then $40^{\circ} \mathrm{C}$. For each temperature at $4 \mathrm{~Hz}$, the optimum value of waste toner is $10 \%$.

\section{Effect of frequency at constant temperature}

At $5^{\circ} \mathrm{C}$, the trend was regular and generally the $\mathrm{RM}$ increases with the increase of frequency $(8 \mathrm{~Hz}>4 \mathrm{~Hz}>1 \mathrm{~Hz})$. At $25^{\circ} \mathrm{C}$, the trend was regular and generally the $\mathrm{RM}$ increases with the increase of frequency $(8 \mathrm{~Hz}>4 \mathrm{~Hz}>1 \mathrm{~Hz})$. The highest values can be seen at $8 \mathrm{~Hz}$ followed by $4 \mathrm{~Hz}$ and then $1 \mathrm{~Hz}$.

At $40^{\circ} \mathrm{C}$, the trend was regular and generally the $\mathrm{RM}$ increases with the increase of frequency $(8 \mathrm{~Hz}>4 \mathrm{~Hz}>1 \mathrm{~Hz})$. All in all, results show that the higher the temperature the better the performance of the pavement with modified asphalt with toner.

Table 4. Effect of Waste Toner on Resilient Modulus

\begin{tabular}{|c|c|c|c|c|c|c|}
\hline Frequency & Temperature & \multicolumn{5}{|c|}{ \% Waste Toner by Volume of Binder } \\
\cline { 3 - 7 } & $\left({ }^{\mathbf{C}} \mathbf{C}\right)$ & 0 & 5 & 10 & 15 & 20 \\
\hline \multirow{3}{*}{1} & 5 & 495 & 692 & 732 & 654 & 583 \\
\cline { 2 - 7 } & 25 & 392 & 448 & 667 & 568 & 408 \\
\cline { 2 - 7 } & 40 & 215 & 280 & 443 & 375 & 240 \\
\hline
\end{tabular}




\begin{tabular}{|c|c|c|c|c|c|c|}
\hline \multirow{4}{*}{4} & $5^{\circ} \mathrm{C}$ & 411 & 712 & 777 & 559 & 520 \\
\cline { 2 - 7 } & $25^{\circ} \mathrm{C}$ & 401 & 600 & 613 & 501 & 474 \\
\cline { 2 - 7 } & $40^{\circ} \mathrm{C}$ & 251 & 323 & 484 & 473 & 291 \\
\hline \multirow{3}{*}{8} & $5^{\circ} \mathrm{C}$ & 450 & 766 & 971 & 903 & 766 \\
\cline { 2 - 7 } & $25^{\circ} \mathrm{C}$ & 436 & 704 & 935 & 750 & 611 \\
\cline { 2 - 7 } & $40^{\circ} \mathrm{C}$ & 425 & 442 & 584 & 541 & 464 \\
\hline
\end{tabular}

\section{Effect of Waste Toner on Creep Stiffness}

Table 5 show sthe relationship between the percentage of waste toner and creep stiffness at different operation conditions of frequencies and temperatures. Following sections present the effect of temperature at constant frequency and the effect of frequency at constant temperature.

\section{Effect of Temperature at Constant Frequency}

At $1 \mathrm{~Hz}$, creep stiffness increases then decreases with the increasing of waste toner content in the binder. The effect of temperature on the creep stiffness was highest at $5^{\circ} \mathrm{C}$ followed by $25^{\circ} \mathrm{C}$ and then $40^{\circ} \mathrm{C}$. For each temperature at $1 \mathrm{~Hz}$, the optimum value of waste toner is $10 \%$. At $4 \mathrm{~Hz}$, creep stiffness increases then decreases with the increasing of waste toner content in the binder. The effect of temperature on the creep stiffness was highest at $5^{\circ} \mathrm{C}$ followed by $25^{\circ} \mathrm{C}$ and then $40^{\circ} \mathrm{C}$. For each temperature at $4 \mathrm{~Hz}$, the optimum value of waste toner is $10 \%$. At $8 \mathrm{~Hz}$, creep stiffness increases then decreases with the increasing of waste toner content in the binder. The effect of temperature on the creep stiffness was highest at $5^{\circ} \mathrm{C}$ followed by $25^{\circ} \mathrm{C}$ and then $40^{\circ} \mathrm{C}$. For each temperature at $4 \mathrm{~Hz}$, the optimum value of waste toner is about $10 \%$.

\section{Effect of Frequency at Constant Temperature}

At $5^{\circ} \mathrm{C}$, the stiffness was slightly decreasing with the increase of frequency $(1 \mathrm{~Hz}>4 \mathrm{~Hz}$ $>8 \mathrm{~Hz}$ ), and the three frequencies showed a maximum point at $10 \%$ waste toner. At $25^{\circ} \mathrm{C}$, the stiffness was slightly decreasing with the increase of frequency $(1 \mathrm{~Hz}>4 \mathrm{~Hz}>$ $8 \mathrm{~Hz}$ ), and the three frequencies showed a maximum point at $10 \%$ waste toner. At $40^{\circ} \mathrm{C}$, the stiffness was slightly decreasing with the increase of frequency $(1 \mathrm{~Hz}>4 \mathrm{~Hz}>8 \mathrm{~Hz})$, and the three frequencies showed a maximum point at $10 \%$ waste toner.

Table 5. Effect of Waste Toner on Creep Stiffness

\begin{tabular}{|c|c|c|c|c|c|c|}
\hline \multirow{2}{*}{$\begin{array}{c}\text { Frequency } \\
(\mathbf{H z})\end{array}$} & $\begin{array}{c}\text { Temperature } \\
\left({ }^{\mathbf{0}} \mathbf{C}\right)\end{array}$ & \multicolumn{5}{|c|}{ \% Waste Toner by Volume of Binder } \\
\cline { 2 - 7 } & 5 & 337 & 390 & 518 & 347 & 291 \\
\hline \multirow{3}{*}{1} & 25 & 265 & 274 & 500 & 324 & 252 \\
\cline { 2 - 7 } & 40 & 215 & 250 & 292 & 280 & 76 \\
\hline
\end{tabular}




\begin{tabular}{|c|c|c|c|c|c|c|}
\hline \multirow{3}{*}{4} & 5 & 224 & 242 & 410 & 324 & 287 \\
\cline { 2 - 7 } & 25 & 149 & 217 & 321 & 242 & 188 \\
\cline { 2 - 7 } & 40 & 126 & 170 & 220 & 217 & 161 \\
\hline \multirow{3}{*}{8} & 5 & 84 & 97 & 150 & 25 & 19 \\
\cline { 2 - 7 } & 25 & 74 & 77 & 136 & 27 & 15 \\
\cline { 2 - 7 } & 40 & 16 & 22 & 27 & 15 & 12 \\
\hline
\end{tabular}

\section{Effect of Waste Toner on Accumulated Strain}

Table 6 shows the results of accumulated strain at different temperatures and frequencies. Following sections present the effect of temperature at constant frequencies $(1,4$, and 8 $\mathrm{Hz})$ and the effect of frequency at constant temperatures $\left(5,25\right.$, and $\left.40^{\circ} \mathrm{C}\right)$.

\section{Effect of Temperature at Constant Frequency}

At $1 \mathrm{~Hz}$, the accumulated strain decreases with increasing waste toner content in the binder. The effect of temperature on the accumulated strain was highest at $40^{\circ} \mathrm{C}$ followed by $25^{\circ} \mathrm{C}$ and then $5^{\circ} \mathrm{C}$. At $4 \mathrm{~Hz}$, the accumulated strain decreases with increasing waste toner content in the binder. The effect of temperature on the accumulated strain was highest at $40^{\circ} \mathrm{C}$ followed by $25^{\circ} \mathrm{C}$ and then $5^{\circ} \mathrm{C}$. At $8 \mathrm{~Hz}$, the accumulated strain decreases with increasing waste toner content in the binder. The effect of temperature on the accumulated strain was highest at $40^{\circ} \mathrm{C}$ followed by $25^{\circ} \mathrm{C}$ and then $5^{\circ} \mathrm{C}$. While the trend of accumulated strain was regular $\left(5>25>40^{\circ} \mathrm{C}\right)$ for all concentrations of waste toner between 0 and $20 \%$.

\section{Effect of Frequency at Constant Temperature}

At $5{ }^{\circ} \mathrm{C}$, it seems that the increase of load decreases slightly the accumulated strain $(1 \mathrm{~Hz}$ $>4 \mathrm{~Hz}>8 \mathrm{~Hz}$ ). At $25^{\circ} \mathrm{C}$, the effect varies considerably from one frequency to another. While it goes down and with the increase of $\%$ waste toner, it goes down at $8 \mathrm{~Hz}$ as the $\%$ waste toner goes up. At $40^{\circ} \mathrm{C}$, there is a general trend that the accumulated strain decreases slightly with the increase of frequency. And the general order of the accumulated strain is $1 \mathrm{~Hz}>4 \mathrm{~Hz}>8 \mathrm{~Hz}$ at a $40^{\circ} \mathrm{C}$.

Table 6. Effect of Waste Toner on Accumulated Strain

\begin{tabular}{|c|c|c|c|c|c|c|}
\hline \multirow{2}{*}{$\begin{array}{l}\text { Frequency } \\
\text { (Hz) }\end{array}$} & \multirow{2}{*}{$\begin{array}{c}\text { Temperature } \\
\left({ }^{\circ} \mathrm{C}\right)\end{array}$} & \multicolumn{5}{|c|}{ \% Waste Toner by Volume of Binder } \\
\hline & & 0 & 5 & 10 & 15 & 20 \\
\hline \multirow[t]{3}{*}{1} & 5 & 11 & 6 & 5 & 4 & 3 \\
\hline & 25 & 22 & 9 & 8 & 6 & 5 \\
\hline & 40 & 30 & 20 & 13 & 12 & 10 \\
\hline \multirow[t]{3}{*}{4} & 5 & 10 & 8 & 7 & 6 & 5 \\
\hline & 25 & 19 & 12 & 10 & 8 & 7 \\
\hline & 40 & 25 & 15 & 13 & 11 & 10 \\
\hline \multirow[t]{2}{*}{8} & 5 & 13 & 11 & 9 & 6 & 5 \\
\hline & 25 & 15 & 12 & 11 & 8 & 7 \\
\hline
\end{tabular}




\begin{tabular}{|l|l|l|l|l|l|l|}
\hline & 40 & 20 & 18 & 16 & 13 & 8 \\
\hline
\end{tabular}

\section{Development of Models}

Regression technique was carried out to develop the following models:

Table 7. Developments of Models for Resilient Modulus (MR)

\begin{tabular}{|c|c|l|c|}
\hline $\begin{array}{c}\text { Frequency } \\
(\mathrm{Hz})\end{array}$ & $\begin{array}{c}\text { Temperature } \\
\left({ }^{\circ} \mathrm{C}\right)\end{array}$ & \multicolumn{1}{|c|}{$\begin{array}{c}\text { Equations } \\
(\mathrm{x}=\% \text { waste toner by Volume of Binder })\end{array}$} & $\mathrm{R}^{2}$ \\
\hline \multirow{4}{*}{1} & 5 & $\mathrm{MR}=-1.8686 \mathrm{x}^{2}+40.131 \mathrm{x}+510.1$ & 0.9207 \\
\cline { 2 - 4 } & 25 & $\mathrm{MR}=-2.1429 \mathrm{x}^{2}+45.897 \mathrm{x}+359.06$ & 0.7685 \\
\cline { 2 - 4 } & 40 & $\mathrm{MR}=-1.8029 \mathrm{x}^{2}+38.957 \mathrm{x}+191.46$ & 0.8314 \\
\hline \multirow{4}{*}{4} & 5 & $\mathrm{MR}=-2.7514 \mathrm{x}^{2}+56.329 \mathrm{x}+445.23$ & 0.7611 \\
\cline { 2 - 4 } & 25 & $\mathrm{MR}=-1.6486 \mathrm{x}^{2}+33.911 \mathrm{x}+425.97$ & 0.7580 \\
\cline { 2 - 4 } & 40 & $\mathrm{MR}=-1.9429 \mathrm{x}^{2}+43.457 \mathrm{x}+221.26$ & 0.8319 \\
\hline \multirow{3}{*}{8} & 5 & $\mathrm{MR}=-3.3686 \mathrm{x}^{2}+82.751 \mathrm{x}+448.97$ & 0.9870 \\
\cline { 2 - 4 } & 25 & $\mathrm{MR}=-3.5143 \mathrm{x}^{2}+78.206 \mathrm{x}+432.29$ & 0.9198 \\
\cline { 2 - 4 } & 40 & $\mathrm{MR}=-1.0657 \mathrm{x}^{2}+24.854 \mathrm{x}+402.51$ & 0.7014 \\
\hline
\end{tabular}

Table 8. Developments of Models for Creep Stiffness (CreepSt)

\begin{tabular}{|c|c|l|c|}
\hline $\begin{array}{c}\text { Frequency } \\
(\mathrm{Hz})\end{array}$ & $\begin{array}{c}\text { Temperature } \\
\left({ }^{\circ} \mathrm{C}\right)\end{array}$ & \multicolumn{1}{|c|}{$\begin{array}{c}\text { Equations } \\
(\mathrm{x}=\% \text { waste toner by Volume of Binder })\end{array}$} & $\mathrm{R}^{2}$ \\
\hline \multirow{4}{*}{1} & 5 & CreepSt $=-1.4771 \mathrm{x}^{2}+26.843 \mathrm{x}+329.74$ & 0.6984 \\
\cline { 2 - 4 } & 25 & CreepSt $=-1.6114 \mathrm{x}^{2}+32.709 \mathrm{x}+237.63$ & 0.5406 \\
\cline { 2 - 4 } & 40 & CreepSt $=-1.52 \mathrm{x}^{2}+25.44 \mathrm{x}+196.2$ & 0.8670 \\
\hline \multirow{4}{*}{4} & 5 & CreepSt $=-1.04 \mathrm{x}^{2}+24.96 \mathrm{x}+203.8$ & 0.6282 \\
\cline { 2 - 4 } & 25 & CreepSt $=-1.22 \mathrm{x}^{2}+26.46 \mathrm{x}+141.8$ & 0.8433 \\
\cline { 2 - 4 } & 40 & CreepSt $=-0.7229 \mathrm{x}^{2}+16.797 \mathrm{x}+119.26$ & 0.9372 \\
\hline \multirow{3}{*}{8} & 5 & CreepSt $=-0.6171 \mathrm{x}^{2}+8.3029 \mathrm{x}+84.543$ & 0.6268 \\
\cline { 2 - 4 } & 25 & CreepSt $=-0.5657 \mathrm{x}^{2}+7.9543 \mathrm{x}+71.114$ & 0.6107 \\
\cline { 2 - 4 } & 40 & CreepSt $=-0.1 \mathrm{x}^{2}+1.7 \mathrm{x}+16.4$ & 0.7576 \\
\hline
\end{tabular}


Table 9. Developments of Models for Accumulated Strain (AccStrain)

\begin{tabular}{|c|c|l|c|}
\hline $\begin{array}{c}\text { Frequency } \\
(\mathrm{Hz})\end{array}$ & $\begin{array}{c}\text { Temperature } \\
\left({ }^{\circ} \mathrm{C}\right)\end{array}$ & \multicolumn{1}{|c|}{$\begin{array}{c}\text { Equations } \\
(\mathrm{x}=\% \text { waste toner by Volume of Binder })\end{array}$} & $\mathrm{R}^{2}$ \\
\hline \multirow{4}{*}{1} & 5 & AccStrain $=0.0229 \mathrm{x}^{2}-0.8171 \mathrm{x}+10.543$ & 0.9529 \\
\cline { 2 - 4 } & 25 & AccStrain $=0.0657 \mathrm{x}^{2}-2.0543 \mathrm{x}+20.686$ & 0.9194 \\
\cline { 2 - 4 } & 40 & AccStrain $=0.0629 \mathrm{x}^{2}-2.2171 \mathrm{x}+29.743$ & 0.9887 \\
\hline \multirow{4}{*}{4} & 5 & AccStrain $=0.0057 \mathrm{x}^{2}-0.3543 \mathrm{x}+9.8857$ & 0.9923 \\
\cline { 2 - 4 } & 25 & AccStrain $=0.0343 \mathrm{x}^{2}-1.2457 \mathrm{x}+18.514$ & 0.9767 \\
\cline { 2 - 4 } & 40 & AccStrain $=0.0514 \mathrm{x}^{2}-1.7086 \mathrm{x}+24.171$ & 0.9582 \\
\hline \multirow{3}{*}{8} & 5 & AccStrain $=0.0029 \mathrm{x}^{2}-0.4771 \mathrm{x}+13.143$ & 0.9778 \\
\cline { 2 - 4 } & 25 & AccStrain $=0.0057 \mathrm{x}^{2}-0.5143 \mathrm{x}+14.886$ & 0.9955 \\
\cline { 2 - 4 } & 40 & AccStrain $=-0.02 \mathrm{x}^{2}-0.18 \mathrm{x}+19.8$ & \\
\hline
\end{tabular}

\section{Development of Comprehensive Models}

The study is concern with 5 levels of waste toner, 3 temperatures, and 3 load frequencies. The following models were developed using statistical package for social science (SPSS) computer software.

$\mathrm{MR}=438.5+49.7(\%$ Toner $)-2.3(\% \text { Toner })^{2}+2.8(\text { Freq. })^{2}-0.2(\text { Temp. })^{2}$

CreepSt $=387.2+19.0$ (\% Toner $)-1.0(\% \text { Toner })^{2}-36.80$ (freq. $)-3.10$ (Temp.)

AccStrain $=14.3-2.6(\% \text { Toner })^{1 / 2}+0.10(\text { Temp. })^{2}$

Where

MR is Resilient Modulus

CreepSt is creep stiffness

AccStrain is Accumulated Strain

\section{CONCLUSIONS}

Based on the results obtained in this study, the following conclusions are drawn:

1. Resilient modulus and creep stiffness increase then decrease with the increasing of percentages waste toner in the binder. 
2. The accumulated micro-strain decreases with the increasing $\%$ waste toner in the asphalt concrete mixtures.

3. A $10 \%$ waste toner content by volume of binder improves the resilient modulus and creep stiffness of asphalt concrete mixtures.

4. Finally it has been concluded that the results are promising for dual achievements (a) to solve an environmental problem and (b) to use the waste toner for flexible pavement.

5. The results of this study were as expected from the references and agree with the study done by Solaimanian et al. (1998)

\section{REFERENCES}

Abu-Salim, Z., Khedaywi, T., Abu-Beker, M., and Raed ababneh, R. ( 2017). "Effect of waste glass on asphalt concrete mixtures." Jordan Journal of Civil Engineering, Volume 11, No 1, January 2017, PP. 117-131.

Al- Massaeid, H., Hamed, M. and Khedaywi,T. ( 1994)."Empirical evaluation of olive husk in asphalt cement binder and bituminous concrete." Transportation Research Record 1436, TRB, National Research Council, Washington, D.C., 124-132.

Alsheyab, M. and Khedaywi, T. (2013). "Effect of electric arc furnace dust (EAFD) on properties of asphalt cement." Resources Conservation and Recycling Journal, 70, 38 $-43$.

Ayers, M. E., and Tripathi, R. (1994). "Incorporation of xerox waste toner material in

asphalt cement and asphalt concrete." Research Report DHT-36, Texas

\section{Department of}

\section{Transportation.}

Button, J., Williams,W.D. and Sherocman, J.A. (1996). "Roofing shingles and toner in asphalt pavements." Research Report 1344-2F, Texas Department of Transportation,

Diamond A. S.(1996)." Toner on the turnpike." R\&R News Magazine, p. 1.

Khedaywi, T.S., Tamimi, A.H. Al-Masaeid, H. and K. Khamaiseh,K.(1993)." Laboratory investigation of properties of asphalt rubber concrete mixtures." Transportation Research Record 1417, TRB, National Research Council, Washington, D.C, pp. 9398.

Khedaywi, T. (2014). "Study on utilising waste toner in asphalt cement." Road Materials and Pavement Design, Volume 15, Issue 2, 446-454.

Mix Design Methods for Asphalt Concrete and Other Hot-Mix Types (2002). Asphalt Institute, MS - 2, U.S.A. 
Solaimanian, M., Kennedy, M. T. and Tripathi.K. (1998). "Performance characteristics

of asphalt binders and mixtures modified by waste toner." Transportation Research

Record No. 1638.

Terrel, R.L. and Epps, J.A. (1998). "Using additives and modifiers in hot mix asphalt." National Asphalt Pavement Association, Quality Improvement Series, Lanham, MD: NAPA, 114. 